чні чинники та можливий патогенез їхньої реалізації. Здоровье Женщиныл. 2017. 2 (118). 26-29.

5. Веропотвелян П.Н., Веропотвелян Н.П., Панасенко А.Н., Горук П.С. (2012). Преждевременное излитие околоплодных вод при недоношенной беременности - что делать? Здоровье женщины. 2012. 1 (67). 99-104.

6. Веропотвелян П.Н., Белая В.В., Веропотвелян Н.П. Современные клинические подходы к лечению угрожающих преждевременных родов. Здоровье женщиныл. 2014. 3. 78-83.

7. Іванюта С.О. Передчасні пологи (Клінічна лекція). Неонатологія, хірургія та перинатальна медицина. 2012. II. 1(3). 71-75.

8. Пірогова В.І., Місюра А.Г. Клінічні варіанти перебігу передчасного розриву плодових оболонок. Перинатальні аспекти. Актуальні питання педіатрії, акушерства та гінекології. Тернопіль. 2015. 2. 147-149.

9. Boots C. E. Bernardi L.A., Stephenson M.D. Frequency of euploid miscarriage is increased in obese women with recurrent early pregnancy loss. Fertility and Sterility. 2014. 102 (2). 455-459.

10. Hubinont C., Debieve F. Профілактика передчасних пологів: новини токолізу. Жіночий лікар. 2012. 2: 21-24.

DOI https://doi.org/10.30525/978-9934-588-81-5-1.17

\title{
THROMBOELASTOGRAPHY IS AN EARLY METHOD OF CONTROL OF HEMOSTASIC DISORDERS DURING PREGNANCY WITH ANTENATAL FETAL DEATH
}

\author{
Hinzburh V. H. \\ $M D$,
}

Professor at the Department of Obstetrics and Gynecology № 3

Bogomolets National Medical University

Gychka N. M.

$P h D$,

Associate Professor at the Department of Obstetrics and Gynecology № 3

Bogomolets National Medical University

Chebotaryova A. S.

Assistant at the Department of Obstetrics and Gynecology № 3, Bogomolets National Medical University 


\section{Beniuk S. V. $P h D$,} Associate Professor at the Department of Obstetrics and Gynecology № 3 Bogomolets National Medical University

Komar V. M.

Doctor-Intern,

Senior Laboratory Assistant at the Department

of Obstetrics and Gynecology № 3

Bogomolets National Medical University

Kyiv, Ukraine

Antenatal protection of the fetus remains an urgent problem of modern obstetrics and perinatal medicine. In the structure of perinatal mortality the main value is contributed by an antenatal fetal death (AFD) which occurs in $78 \%$ of cases, and has a negative impact on both women and medical staff $[1$, p. 8] Prediction and prevention of complications during pregnancy that can lead to AFD are not possible without a detailed analysis and proper diagnostics of each case. It is important to keep in mind the physiological tendency to hypercoagulability during pregnancy. Early changes in hemostasis can be detected by throtboelastography (TEG). First of all, these changes relate to the density of the thrombus forming due to fibrinogen. According to the literature, the dynamics of thrombosis ( $\mathrm{R}$ and $\mathrm{K}$ thromboelastogram) in the third trimester, although prone to shortening, but do not go beyond physiological values. Although the indicator of the maximum amplitude (MA) of the curve at the end of pregnancy exceeds the standard norm by $15-20 \%$ [2, p. 462-463]. In the presence of extragenital pathology (antiphospholipid syndrome, obesity, cardiovascular disease, diabetes) or complications of pregnancy (placental dysfunction, preeclampsia) in the vascular bed are biologically active substances that affect the coagulant part of coagulation system leading to blood clotting in the spiral vessels, excessive fibrin formation [3, p. 99-102]. They also have a diagnostically important effect on the anticoagulant mechanisms of the hemostasis system: a decrease in antithrombin III, protein - $\mathrm{C}$ and an increase of the activity on the fibrinolysis system [4, p. 24-31].

The purpose of the study: to determine the place of thromboelastography in the early diagnosis of the hemostatic disorders in women with antenatal fetal death.

Materials and methods of the study: The prospective survey included 32 women with AFD during pregnancy and postpartum period in the time period from 2018 to 2020 on the basis of the UNE «Kyiv City Maternity 
Hospital № 3». The control group consisted of pregnant women with the physiological course of pregnancy and childbirth without any significant extragenital pathology $(n=35)$. The hemostasis system was studied by coagulogram and thromboelastography. To assess hemostasis in pregnant women, blood samples were taken at the diagnosis of «antenatal fetal death», immediately after birth and on the 3rd day of the postpartum period.

The results of the study and their discussion: In the main group of pregnant women all the results of thromboelastograms were outside the normal range, while in the control group the parameters of thromboelastography were within the physiological values. The parameter $\mathrm{R}$ characterizes the time required for the formation of active thromboplastin. Norm from 9 - 27. In patients with AFD, this rate is reduced by $21 \%$ ( $p>0.05)$. The parameter $\mathrm{K}$ - corresponds to the beginning of the coagulation phase $(\mathrm{N}=2-9 \mathrm{~min}$ ), in the main group decreased by $28.2 \%$ ( $\mathrm{p}>0.05$ ) against to the control group. Analysis of changes in parameter $\mathrm{K}$ indicates the presence of hemostatic disorders in women with AFD in the form of increased platelet activity and hyperaggregation. $\alpha$-angle is an indicator that reflects the rate of formation of the fibrin network and its structure $(\mathrm{N}=22-59)$. In the main group, this figure is increased by $16.8 \%$ ( $>>0.05$ ) against to the control group. The MA parameter corresponds to the end of the productive phase of blood coagulation, after which the refraction of the clot begins. The reference value is $42-64 \%$. In women of the main group this indicator is increased by $16.4 \%$. It should be noted that during performing the analysis with the use of standard coagulogram in women with AFD, there was no significant difference in the hemostasis system compared to pregnant women with physiological course, APTT $=17-20 \mathrm{sec}$, fibrinogen up to $6.5 \mathrm{~g} / \mathrm{l}, \mathrm{IF}=78-142 \%$ To calculate the correlation, the indicators of coagulation rate in thromboelastography $(\mathrm{R}, \mathrm{K}, \alpha)$ and coagulogram (APTT, IF), indicators of clot density (MA, fibrinogen) were compared. The calculation of correlation coefficients was performed by the nonparametric Spearman method, because due to differences in approaches to the analysis, the presence of a direct mathematical relationship was established. There are also changes in the D-dimer and clot lysis, but this indicator was determined only in 6 cases of the main group and cannot be considered statistically significant. While comparing the indicators of thromboelastography (R, K, angle $\alpha, \mathrm{MA}$ ) and the standard coagulogram (APTT, IF, fibrinogen) in the postpartum period, the indicators of the hemostasis system did not differ significantly. In pregnant women with AFD during admission to the hospital changes in the hemocoagulation system such as increased platelet aggregation, moderate hypercoagulation and inhibited 
fibrinolysis were revealed. This is evidenced by an increase of such indicators as MA, CFT, CT, and MCF compared to the normal values. Although according to the standard coagulogram, the indicators in the main and control groups were within the reference values. At the same time, according to the standard coagulogram, it was found that patients with AFD after childbirth had shortened APTT by $13.7 \%(p<0.05)$ from the limit, the prothrombin index in the first group was reduced by $15.3 \%(\mathrm{p}<0.05)$. Compared with women in the control group, the APTT was normal. The content of fibrinogen in women with physiological course exceeded the normal level by $35.7 \%$ ( $\mathrm{p}<0.05$ ), and in women of the main group there was an excess of $87 \%(\mathrm{p}<0.05)$. Identical changes in the hemostasis system were observed with TEG. It is important that such changes in the hemostasis system are difficult to correct with standardized therapy.

Conclusions. Thus, our study showed that the method of thromboelastography is the earliest and most informative method of assessing hemostasis in pregnant women with AFD. The advantages of usage TEG in such pathological conditions in obstetrics are following: firstly, the study is performed on unaltered blood, does not require additional laboratory equipment and multicomponent examination of all pathways of the blood coagulation system (plasma, platelet and fibrinolytic). Secondly, the advantage is the speed, and simplicity of this examination, and thirdly, the patient's body temperature is taken into account automatically.

\section{References:}

1. Zakharkov VI, Panchyshyn IV Abstracts 82 - scientific-practical conference of students and young scientists with international participation «Innovations in Medicine» Structure of antenatal fetal death (according to retrospective analysis of medical records.

2. Bulanov, A. Yu., Prasolov, NV, \& Yatskov, KV (2014). Thromboelastography in the practice of anesthesia and intensive care in obstetrics. Clinical recommendations. Treatment protocols. Peoples' Friendship University of Russia City Clinical Hospital, (52), 462-463.

3. Zaporozhyan, VN, et al. Diagnosis, prevention and complex correction of activation of the fibrinolytic component of the hemostasis system in pregnant women with placental abruption. Women's Health, 2013, 1: 99-102.

4. Bitsadze, V. O. et al. Thrombophilia as an important part in the pathogenesis of pregnancy complications. Practical Medicine, 2012, 9 (65). 